\title{
Strategi Komunikasi Politisi Perempuan
}

\author{
Muhammad Edy Susilo dan Nurul Latifatun Nisa \\ Program Studi Ilmu Komunikasi UPN Veteran Yogyakarta \\ Email: muh_edy_susilo@yahoo.co.id
}

\begin{abstract}
Since Indonesia's political reform in 1998, women's quota in the legislature has become an important issue. This aspiration was successfully established as a political policy that accommodates affirmative action for women in parliament. The purpose of this policy is to ensure the implementation of pro-women rules. However, after 10 years, the $30 \%$ quota for women in the legislature has not been maximally implemented. Several regions in Indonesia show different developments in this regard. This research was conducted in Minahasa District with the highest number of female legislative representatives in Indonesia and in Wonosobo District with the fewest female representation in the legislature in Indonesia. This study uses experimental methods and qualitative analysis. The experiment was conducted to find out how respondents assessed the rhetorical ability of female politicians and male politicians. The results of the experiment were then further investigated by in-depth interviews and focus group discussions. Research shows that male respondents view male politicians as having more abilities than female politicians. Meanwhile, female respondents also saw male politicians more competent. This is in line with gender stereotyping theory. Women politicians who have qualified political communication skills have the opportunity to be elected in political circles. The social structure also influences the choice of women as politicians. In Wonosobo district, some religious circles do not allow women to become legislators or become public officials.
\end{abstract}

Keywords: affirmative action, gender stereotyping, rhetorical ability

\begin{abstract}
Abstrak
Sejak reformasi digulirkan pada tahun 1998, isu mengenai kuota perempuan di legislatif mengemuka. Isu ini berhasil ditetapkan menjadi sebuah kebijakan politik yang mengakomodir affirmative action bagi perempuan di parlemen. Tujuan kebijakan ini adalah untuk memastikan implementasi aturan yang pro perempuan. Beberapa daerah di Indonesia menunjukkan perkembangan yang berbeda-beda. Penelitian ini dilakukan di Kabupaten Minahasa dengan jumlah perwakilan anggota legislatif terbanyak di Indonesia dan di Kabupaten Wonosobo dengan jumlah perwakilan perempuan di legislatif paling sedikit di Indonesia. Penelitian ini menggunakan metode eksperimen dan analisis kualitatif. Eksperimen dilakukan untuk mengetahui bagaimana responden menilai politisi perempuan dan politisi laki-laki kemudian diteliti lebih lanjut dengan wawancara mendalam dan focus group discussion. Penelitian menunjukkan bahwa responden laki-laki memandang politisi laki-laki lebih memiliki kemampuan dari pada politisi perempuan. Sementara, responden perempuan juga melihat politisi laki-laki lebih kompeten. Hal ini sejalan dengan teori gender stereotiping. Politisi perempuan yang memiliki keahlian komunikasi politik yang mumpuni memiliki kesempatan untuk dapat terpilih dalam lingkaran politik. Struktur sosial juga mempengaruhi keterpilihan perempuan sebagai politisi. Di kabupaten Wonosobo, sebagian kalangan agama tidak menyetujui perempuan menjadianggota legislatif
\end{abstract}

Kata kunci: affirmative action, gender stereotiping, politisi, ulama, parlemen 


\section{Pendahuluan}

Reformasi politik di Indonesia tahun 1998 menjadi momentum banyak perubahan pada kehidupan bernegara. Salah satu perubahan penting yang terjadi adalah mengenai keterwakilan perempuan di lembaga legislatif. Pada awalnya, isu ini berasal dari lingkaran aktifis perempuan. Mereka menyoroti rendahnya keterwakilan perempuan di parlemen pada masa Orde Baru. Gugatan ini muncul dari keterwakilan yang tidak seimbang di parlemen dibandingkan dengan jumlah pemilih yang lebih didominasi oleh pemilih perempuan. Di sisi lain, Indonesia telah lama mengesahkan Undang-Undang (UU) No. 68 Tahun 1958 tentang Ratifikasi Konvensi Hak Politik Perempuan. Di dalamnya, mengatur mengenai Perwujudan Kesamaan Kedudukan (non diskriminasi), jaminan persamaan hak memilih dan dipilih, jaminan partisipasi dalam perumusan kebijakan, kesempatan menempati posisi jabatan birokrasi, dan jaminan partisipasi dalam organisasi sosial politik. Dukungan terhadap keterwakilan perempuan di parlemen belum bisa diwujudkan pada pemilu pertama setelah reformasi yakni tahun 1999. Kebijakan yang kemudian dikenal sebagai kebijakan afirmasi (affirmative action) terhadap perempuan dalam bidang politik baru dilaksanakan setelah berlakunya perubahan UUD 1945 dimulai dengan disahkannya UU Nomor 12 Tahun2003 tentangPemiluDPR,DPD, danDPRD.

Affirmative action terhadap perempuan dalam bidang politik semakin disempurnakan. Hal itu dapat ditelaah ketika DPR menyusun RUU Paket Politik yang digunakan dalam pelaksanaan Pemilu 2009, yaitu UU No. 22 Tahun 2007 tentang Penyelenggara Pemilu, UU No. 2 Tahun 2008 tentang Partai Politik dan UU No. 10 Tahun 2008 tentang Pemilu DPR, DPD, dan DPRD. UU No. 22 Tahun 2007 tentang Penyelenggara Pemilu mengatur agar komposisi penyelenggara Pemilu memperhatikan keterwakilan perempuan minimal 30\%. Pasal 6 ayat (5) UU tersebut menyatakan bahwa : "Komposisi keanggotaan KPU, KPU Provinsi, dan KPU Kabupaten/
Kota memperhatikan keterwakilan perempuan sekurang-kurangnya30\%(tigapuluh perseratus)".

Pada kelembagaan partai politikpun, affirmative action dilakukan dengan mengharuskan partai politik menyertakan keterwakilan perempuan minimal $30 \%$ dalam pendirian maupun dalam kepengurusan di tingkat pusat. UU No. 2 Tahun 2008 tentang Partai Politik yang mengatur syarat pendirian Partai Politik, pada Pasal 2 menyatakan "Pendirian dan pembentukan Partai Politik sebagaimana dimaksud pada ayat (1) menyertakan 30\% (tiga puluh perseratus) keterwakilan perempuan". Berbagai upaya yang dilakukan pemerintah dan organisasi perempuan untuk meningkatkan keterwakilan perempuan di parlemen, belum menunjukkan hasil yang diharapkan. Pada Pemilu 1999 atau sebelum diterapkannya affirmative action, keterwakilan perempuan di parlemen sebanyak 9,0\%, maka pada Pemilu 2004 atau setelah diterapkannya affirmative action, keterwakilan perempuan hanya naik tipis menjadi $11,8 \%$. Pada pemilu selanjutnya, tahun 2009, naik menjadi 18,2\% (Mulyono, 2010).

Proporsi anggota legislatif perempuan yang terpilih juga gagal mencapai affirmative action 30 persen pada Pemilu 2014. Justru proporsi tersebut mengalami penurunan dari $18,2 \%$ pada tahun 2009 menjadi 17,3\% di tahun 2014. Padahal, kandidat perempuan yang mencalonkan diri dan masuk dalam daftar pemilih dari partai politik mengalami peningkatan dari $33,6 \%$ tahun 2009 menjadi $37 \%$ pada 2014.

Pada Pemilu Legislatif tahun 2014, ternyata hanya mampu menghasilkan keterwakilan perempuan di legislatif sebanyak 97 kursi $(17,32$ persen) di DPR, 35 kursi (26,51 persen) di DPD, dan rata-rata 16,14 persen di DPRD serta 14 persen di DPRD kabupaten/kota (http://www.beritasatu. com/nasional/210327-kuota-30-keterwakilanperempuan-di-parlemen-gagal-tercapai.html)

Selain itu juga ditemukan jika di DPD, DPR, dan DPRD provinsi mengalami penurunan jumlah kursi perempuan. Dari 33 DPRD provinsi, ada satu DPRD provinsi yang kursi 
perempuannya mencapai 30\% lebih, yaitu DPRD Sulawesi Utara. Kursi perempuan yang tertinggi ada di DPRD Kabupaten Minahasa yaitu 42,86\% (15 dari 35 kursi) (Republika.co.id).

Untuk proporsi kursi terrendah saat hanya terdapat 2 orang perempuan yang duduk sebagai anggota dewan di Wonosobo. Jumlah tersebut artinya hanya $4,4 \%$ dari jumlah keseluruhan anggota dewan yang 45 orang. Polaritas di antara dua daerah tersebut dapat dijadikan gambaran bahwa wacana partisipasi politik perempuan masih memiliki tantangan. Bisa jadi, ini hal tesebut karena potensi politisi perempuan belum dimaksimalkan sepenuhnya. Kendala bias gender yang masih mengakar di Indonesia berefek pada penilaian pemilih. Disinilah keahlian komunikasi politik yang efektif diperlukan agar politisi perempuan dapat mempersuasi dan memobilisasi massa.

Peneliti menawarkan untuk menguji sejauh mana partisipan politik masih menganggap politik hanya milik laki-laki lewat analisis gender stereotyping. Setelah itu membuat model strategi komunikasi politik yang efektif untuk memaksimalkan potensi politisi perempuan. Penelitian ini memanfaatkan pre research mengenai gender stereotying dan dilanjutkan dengan analisis kualitatif potensi politisi perempuan. Hasil yang didapatkan lalu dijadikan modal untuk penyusunan model strategi komunikasi politik bagi politisi perempuan.

Berdasarkan uraian di atas, penelitian ini merumuskan masalah penelitian untuk dipecahkan sebagai berikut, seberapa besar gender stereotyping mempengaruhi pemilih dalam menilai kemampuan komunikasi politik dari kandidat. Penelitian ini bertujuan mengidentifikasi gender factor yang mempengaruhi penilaian pemilih kemampuan komunikasi politik kandidat dan memberikan gambaran mengenai kemampuan komunikasi politik kandidat yang ideal. Partai politik dan kader menggunakan kampanye saat pemilihan untuk menggalang suara. Politisi atau kader perempuan sesungguhnya memiliki ketrampilan yang sayangnya belum dimanfaatkan secara maksimal saat kampanye pemilihan. Hal ini terbukti dengan minimnya jumlah kader perempuan yang dipilih di sektor politik strategis. Keahlian perempuan dalam berpolitik terutama di bidang komunikasi perlu diperkuat. Tujuannya adalah memberikan peluang yang sama agar bisa terpilih. Bentuk strategi yang bisa dilakukan yakni pengembangan kemampuan berkomunikasi politik bagi perempuan agar dapat menjangkau konstituen.

Untuk mencapai tujuan tersebut peneliti menawarkan strategi komunikasi yang proaktif sehingga dapat menghilangkan bias gender. Jika kader telah terlatih dengan baik, hal ini dapat juga mendorong partai politik untuk meningkatkan pemunculan kader perempuan. Kehadiran politisi atau kader perempuan yang ideal tanda kesetaraan gender yang terwakili dalam kepengurusan dan demokrasi bangsa.

Kebanyakan di negara demokrasi modern, kesetaraan antara laki-laki dan perempuan telah menjadi wacana politik. Pria dan wanita harus alami memiliki hak yang sama dan tidak ada yang harus dikeluarkan dari kehidupan politik. Namun demikian, ada perbedaan substansial baik antar negara dan antar bidang politik y berapa banyak dan apa jenis kesetaraan yang dimaksud. Ada beberapa alasan mengapa beberapa negara atau beberapa daerah kebijakan lebih mengedepankan kesamaan gender. Berkaitan dengan rezim dan kelembagaan, unsur-unsur budaya dapat diguanakan untuk menjelaskan mengapa politik umumnya masihdidominasioleh politisilaki-laki.

Seiring peningkatan jumlah perempuan mencalonkan diri untuk pemilihan lokal, propinsi, dan nasional, perlahan-lahan mengikis sifat dari kampanye pemilu yang didominasi laki-laki. Bermunculan penelitian dalam reaksi pemilih untuk calon perempuan. sebagian besar penelitian terbaru ini difokuskan pada elektabilitas calon perempuan dalam upaya untuk mengungkap bias pemilih. Penelitian tersebut mengungkap representasi perempuan yang umumnya lebih rendah khususnya di tingkat nasional.

Bahwa calon yang berbeda gender dianggap memiliki area kompetensi yang berbeda 
tidak selalu dianggap negatif bagi popularitas kandidat dan partai mereka. Perempuan mungkin ditempatkan untuk kebijakan yang berbeda. Idenya adalah bahwa politisi perempuan membuka dimensi baru persaingan partai dengan menekankan isu-isu baru. Politisi perempuanjuga dapat memperkenalkan dimensi baru kompetensi pribadi ke politik. Isu "kebaruan" mereka tidak berarti melepaskan sifat-sifat pribadi perempuan. Jika memang gender stereotyping dapat mempengaruhi persepsi pemilih, gender lalu dapat dikaitkan dengan persepsi lainnya. Seperti kemampuan kandidat untuk berkomunikasi, membawa atmosfer hangat ke dunia politik, dan kapasitasnya untuk membujuk pemilih.

Jika politisi perempuan dikaitkan keterampilan pribadi yang berbeda, hal ini juga berdampak pada popularitas mereka dan popularitas partai yang mereka wakili. Jumlah pemilih yang kian bertambah tiap periodenya. Dengan demikian, partai dan kandidat politik perlu mahir berkomunikasi untuk memobilisasi pemilih. Stereotype dekat dengan keseharian manusia. Diakui atau tidak, stereotype sering dianggap sebagai jalan pintas untuk mendapatinformasi. Stereotype digunakankarena individu belum mendapatkan informasi penuh terhadap sesuatu, sehingga menggantungkan pada gambaran konvensional yang disederhanakan.

Bukan tidak mungkin pemilih menggunakan gender sebagai jalan pintas informasi untuk menakar kualitas politisi, sama halnya saat mereka menggunakan karakteristik demografis atau sikap berat sebelah untuk mengevaluasi kandidat politik (Popkin, 1991). Sedangkan keberpihakan sering menjadi karakteristik relevan untuk menilai kandidat politik. Gender stereotype bisa menyesatkan dan memiliki dampak negatif pada proses kaderisasi perempuan untuk lebih terlibat dalam politik.

Isu gender stereotyping menjadi lebih kuat di masyarakat yang kental dengan isu publik dan domestik. Penilaian kinerja peran perempuan atau laki-laki didasarkan pada ekspektasi masing-masing. Jika ada politisi yang menyimpang dari ranah gender, maka tak jarang menjadi bahan perbincangan. Indonesia sudah pernah memiliki Presiden, Menteri, Walikota dan kader partai dari kalangan perempuan. Meski demikian, pandangan masyarakat atas kualitas politisi perempuan dalam memerankan isu publik masih menjadi tantangan. Padahal, rasanya lebih relevan apakah perempuan dan laki-laki dinilai dengan standar yang sama.

Dalam negara yang menganut sistem nilai patriarkal, seperti Indoenesia, kesempatan perempuan untuk menjadi politisi relatif terbatasi karena persepsi masyarakat mengenai pembagua peran antara laki-laki dan perempuan, yang cenderung bias kearah membatasi peran peremppuan wanita pada urusan rumah tangga (Parawansa, 2002: 43). Matland menemukan jika bias gender berkorelasi dengan kemampuan kandidat politik untuk berargumentasi. Pengamat politik menganggap bahwa karakter individu baik yang tayang dimedia maupun secara langsung, menjadi penting dan dijadikan penilaian oleh pemilih (Jenssen \& Aalberg 2006). Feminis menekankan bahwa peran media sebagai "antithesis relationship of women and politics" (Sreberny \& Van Zoonen, 2000).

Teori yang digunakan adalah pendekatan retorika klasik, yakni seni persuasi, ethos, dan pathos. Ethos: pengetahuan dan sifat dapat dipercaya. Pathos yang kita kenal sebagai gaya berbicara dengan bertujuan menyentuh emosi di representasikan dengan "optimistis", "penuh harapan", "menggelisahkan", "mengkhawatirkan". Ethos dan pathos juga bisa dikaitkan dengan penelitian Marcus $(1988$;1991) yang berisikan pondasi pesan emosional dalam kampanye politik. Sifat "menginspirasi" dan "membosankan" dapat berelasi dengan konsep pidato yang berkarisma. Selain itu "meyakinkan" dan "tidak relevan" mengekspresikan penerimaan atau penolakan.

Memaksimalkan potensi dari politisi perempuan dapat diawali dengan mengenalkan cara berkomunikasi yang efektif. Bentuk komunikasi politik yang proaktifmengedepankan kemampuan kandidat dalam beretorika. Yakni bagaimana teknik komunikasi dengan 
wartawan dan teknik berbicara di depan umum. Komunikasi politik yang proaktif dan efektif dapat mewujudkan politisi yang dikenal dan berkesempatan menjaring suara. Komunikator yang populer dapat lebih mudah memberikan pengaruh dalam proses komunikasi. Hal ini dapat menguntungkan karena politisi yang merupakan komunikator memiliki posisi strategis. Politisi dapat memainkan peran politik dengan suatu setting tertentu. Agar dapat meyakinkan publik, politisi perlu tampil sebagai komunikator professional, yakni dapat memberi saran tentang kondisi politik tertentu, melakukan personal branding dalam kampanye politik, sekaligus dapat melayangkan argumentasi yang jitu.

\section{Metode Penelitian}

Penelitian ini menggunakan sinergi dari dua metode atau mix method atau multiple method yang menerapkan penelitian kuantitatif dan kualitatif. Penelitian diawali dengan menggunakan metode eksperimental dan dilanjutkan dengan pendekatan thick description kualitatif. Sinergi dua metode bermaksud memberikan deskripsi menengenai gender factor yang mempengaruhi penilaian pemilih terhadap kemampuan komunikasi politik kandidat. Lalu hasilnya dapat dimanfaatkan dalam proses penyusunan materi strategi komunikasi mengenai kemampuan berkomunikasi kandidat politik yang ideal. Dari langkah-langkah ini peneliti dapat membuat model strategi komunikasi politik yang dapat diterapkan untuk mengoptimalkan potensi politisi perempuan.

Pada tahap awal, desain kuesioner untuk penelitian eksperimental menekankan pada struktur pidato politik yang baik. Objek penelitian diminta menilai dan memberikan opini dari elemen dan struktur pidato yang ditayangkan. Seberapa banyak pemilih yang setuju atau tidak setuju dengan pernyataan. Skala yang digunakan adalah 0-10. Dimana angka 0 menunjukkan tanda sangat tidak setuju dan 10 artinya sangat setuju.

Secara konvensional metode kualitatif cenderung diasosiasikan dengan keinginan peneliti untuk menelaah makna, konteks, dan suatu pendekatan holistik terhadap fenomena. (Hayes dalam Mulyana, 2007: 6). Penelitian deskriptif merupakan penelitian yang meneliti status sekelompok manusia, suatu obyek, suatu kondisi yang bertujuan untuk memberikan gambaran secara sistematis, faktual dan aktual mengenai fakta-fakta, sifat-sifat serta hubungan antar fenomena yang akan diselidiki.

Pre-researchberupamodel posttestcontrol group design. Jenis penelitian ini merupakan True Experiment. Responden dalam pre research adalah partisipan politik. Dimana ada dua macam perlakuan pada dua kelompok eksperimen dan satu kelompok control. Pre research dilakukan dengan post treatment kuesioner.

Treatment yang dipakai adalah video rekaman yang berisikan pidato orisinal yang diberikan oleh kandidat lalu diperankan oleh perempuan dan laki-laki yang berakting sebagai kandidat. Video ditampilkan pada sampel dari pemilih pertama, di mana beberapa grup secara acak menonton kandidat perempuan. Kelompok lain menonton kandidat laki-laki. Tiap partisipan hanya menonton video satu kali.

Langkah kedua adalah menggunakan metode kualitatif thick description. Setelah melakukan interpretasi pre-research, dilanjutkan dengan teknik mengumpulkan data guna penyusunan model strategi komunikasi melalui observasi potensi politisi perempuan, wawancara mendalam pada informan yaitu politisi (kader) partai perempuan, pimpinan partai, aktifis perempuan, tokoh masyarakat, dan masyarakat. Focus Group Discussion (FGD) dengan melibatkan perwakilan elemen politisi politik perempuan dari Kabupaten Minahasa dan Kabupaten Wonosobo.

\section{Hasil Penelitian dan Pembahasan}

Perempuanmemilikisuarasebagaipemilih dan menjadi mayoritas penduduk di Indonesia. Hak pilih perempuan dapat menghasilkan perubahan. Selain suara sebagai pemilih, perempuan juga bisa turut serta berpartisipasi dalam iklim politik dengan menjadikan dirinya sebagai politisi. Keikutsertaan perempuan 
untuk turut membangun Negara, menunjukkan adanya keinginan mendapatkan kesetaraan hak dan kewajiban dalam berpolitik. Dari 33 DPRD provinsi di Indonesia, ada satu DPRD provinsi yang kursi perempuannya mencapai $30 \%$ lebih, yaitu DPRD Sulawesi Utara. Kursi perempuan yang tertinggi ada di DPRD Kab. Minanhasa yaitu 42,86\% (15 dari 35 kursi) (Republika.co.id).

Untuk proporsi kursi terendah di legislatif, saat hanya terdapat 2 orang perempuan yang duduk sebagai anggota dewan di Wonosob. Jumlah tersebut artinya hanya $4,4 \%$ dari jumlah keseluruhan anggota dewan yang 45 orang. Persentase keterwakilan perempuan di lembaga legislatif Kabupaten Wonosobo relatif kecil dari pemilu ke pemilu, sejak reformasi ratarata hanya $7 \%$ dari 45 jumlah kursi rakyat. Hasil pemilu tahun 1999-2004 hanya 4 orang dari PPP, Partai Golkar, PKB dan PDIP. Tahun 2004-2009 hanya 3 orang dari PDIP, PPP dan PAN. Tahun 2009-2014 juga hanya 3 dari PAN, PDIP dan Partai Golkar dan pada Pemilu 20142019 juga 2 orang dari Nasdem, kemudian ada satu anggota pengganti antarwaktu dari partai Golkar. Namun, dalam pencalonan sebagi anggota legislatif, rata-rata quota $30 \%$ caleg perempuan di semua partai sudah terpenuhi. Polaritas di antara dua daerah tersebut dapat dijadikan gambaran bahwa wacana partisipasi politik perempuan masih memiliki tantangan. Bisa jadi, ini hal tesebut karena potensi politisi perempuan belum dimaksimalkan sepenuhnya. Kendala bias gender yang masih mengakar di Indonesia berefek pada penilaian pemilih. Disinilah keahlian komunikasi politik yang efektif diperlukan agar politisi perempuan dapat mempersuasi dan memobilisasi massa.

\section{Analisis Eksperimen Gender Stereotyping}

Perbandingan yang disajikan pada Tabel

1 adalah hasil dari proses eksperimen pada responden yang melihat video kandidat lakilaki atau melihat kandidat perempuan. Pola keseluruhannya terlihat cukup jelas. Kandidat laki-laki dianggap oleh responden memiliki kinerja lebih baik dari kandidat perempuan. Pada enam dari sembilan fitur, skor untuk kandidat lakilaki lebih tinggi. Sedangkan untuk tiga indicator sifat lainnya, kandidat perempuan mencapai nilai yang lebih tinggi meski dengan selisih tipis. Sifat yang dimaksud adalah penilaian mengenai isi pidato yang dianggap memiliki pengetahuan, memberikan harapan, dan terlihat optimis.

Data tersebut memperlihatkan bahwa pidato terlihat lebih menyenangkan, dapat dipercaya, relevan, meyakinkan, memberi inspirasi, dan menenangkan hati jika dilakukan oleh kandidat laki-laki digunakan. Meski dinilai jika isi pidato memberikan pengetahuan dan bernada optimis memberi harapan, responden tidak menganggap bahwa kandidat perempuan cukup dapat dipercaya integritasnya sebagai politisi. Responden lebih memilih kandidat laki-laki yang membawakan pidato dan dianggap lebih meyakinkan.

\begin{tabular}{|l|l|l|l|}
\hline \multicolumn{4}{|c|}{ Tabel 1. Mean Penilaian Isi Pidato } \\
\hline No & Speech Traits & $\begin{array}{l}\text { Kandidat } \\
\text { Perempuan }\end{array}$ & $\begin{array}{l}\text { Kandidat } \\
\text { Laki Laki }\end{array}$ \\
\hline 1 & Pengetahuan & $\mathbf{7 . 1 0}$ & 6.40 \\
\hline 2 & Menyenangkan & 4.30 & 6.00 \\
\hline 3 & Dipercaya & 5.40 & 6.60 \\
\hline 4 & Relevan & 7.00 & 7.50 \\
\hline 5 & Meyakinkan & 6.00 & 6.40 \\
\hline 6 & Menginspirasi & 6.30 & 6.40 \\
\hline 7 & Menenangkan & 5.10 & 5.60 \\
\hline 8 & Harapan & $\mathbf{7 . 0 0}$ & 6.50 \\
\hline 9 & Optimis & $\mathbf{7 . 6 0}$ & 6.90 \\
\hline
\end{tabular}




\section{Penilaian Kandidat Berdasarkan Gender Responden}

Saat gender dimasukkan dalam bahan analisis, ditemukan perbedaan bagaimana responden laki-laki dan perempuan dalam mengevaluasi kandidat yang memiliki jenis kelamin sama. Salah satu asumsi awal penelitian adalah, bahwa voter akan lebih menyukai kandidat dari jenis kelamin mereka sendiri.

Terlihat dalam Tabel 2, hasilnya menarik. Tidak ditemukan dukungan yang jelas untuk asumsi solidaritas gender secara keseluruhan. Umumnya terdapat perbedaan kecil dan tidak signifikan dalam bagaimana wanita mengevaluasi kandidat laki-laki dan perempuan. Ini menunjukkan bahwa gender tampaknya tidak penting bagi perempuan. Beralih ke nilai kandidat pria, maka kisahnya menjadi berbeda. Pria menilai kandidat laki-laki secara lebih baik pada kebanyakan indikator. Dua pernyataan di mana pria menilai kandidat perempuan lebih tinggi adalah dua sifat yang merupakan sifat naluri yang banyak dimiliki perempuan, yakni memberikan harapan dan optimisme. Meski jauh dari signifikan, pria dalam sampel penelitian menganggap pidato tersebut agak membosankan dan lebih tidak relevan saat dilakukan oleh kandidat perempuan.

Sementara, analisis yang dilakukan menggunakan pendekatan korelasi bivariat sederhana. Selanjutnya dilakukan analisis multivariate semua faktor. Fokus pada
4 dimensi: pengetahuan, kepercayaan, meyakinkan dan memberi inspirasi. Analisis regresi mengkonfirmasi bahwa adanya hubungan yang signifikan antara gender kandidat dan kemampuan komunikasi, bahkan setelah peneliti mengendalikan faktor lainnya.

Model 1 memberikan control pertama untuk variabel rangsangan saat jenis kelamin responden dan kepentingan politik. Model 2 menjalankan fungsi kontrol yang sama, namun dalam model ini kita menyelidiki adanya kemungkinan efek interaksi antara rangsangan dan jenis kelamin responden. Dari teori di awal, adanya teori skema gender yang menunjukkan bahwa sikap "pilih kasih" pada gender tertentu mungkin terjadi, sehingga pria lebih menyukai kandidat laki-laki dan perempuan akan menyukai kandidat perempuan.

Analisis bivariat pada Tabel 2 menunjukkan bahwa perilaku seperti ini hanya berlaku untuk pria. Hal ini ditegaskan pada Model 2. Responden pria yang melihat kandidat laki-laki lebih cenderung memandang pidato sebagai lebih berpengetahuan, dapat dipercaya, meyakinkan danmemberiinspirasi,menghasilkan koefisien beta standar yang signifikan .19. Wanita yang terpapar calon perempuan masih menganggap pidato tersebut agak lebih positif daripada yang lain, namun hubungannya lemah dan tidak signifikan. Sejauh ini, menunjukkan bagaimana persepsi kemampuan komunikasi kandidat dipengaruhi oleh stereotip gender.

Tabel 2. Mean Per Gender

\begin{tabular}{|l|l|l|l|l|l|}
\hline & & \multicolumn{3}{|l|}{ Responden Laki Laki } & \multicolumn{2}{l|}{ Responden Perempuan } \\
\hline No & Speech Traits & $\begin{array}{l}\text { Kandidat } \\
\text { Perempuan }\end{array}$ & $\begin{array}{l}\text { Kandidat } \\
\text { Laki Laki }\end{array}$ & $\begin{array}{l}\text { Kandidat } \\
\text { Perempuan }\end{array}$ & $\begin{array}{l}\text { Kandidat } \\
\text { Laki Laki }\end{array}$ \\
\hline 1 & Pengetahuan & 7.00 & 6.40 & 7.20 & 6.40 \\
\hline 2 & Menyenangkan & 3.40 & 5.80 & 5.20 & 6.20 \\
\hline 3 & Dipercaya & 5.00 & 6.60 & 5.80 & 6.60 \\
\hline 4 & Relevan & 7.20 & 8.00 & 6.80 & 7.00 \\
\hline 5 & Meyakinkan & 5.60 & 5.80 & 6.40 & 7.00 \\
\hline 6 & Menginspirasi & 6.00 & 6.00 & 6.60 & 6.80 \\
\hline 7 & Menenangkan & 4.40 & 5.40 & 5.80 & 5.80 \\
\hline 8 & Harapan & 6.80 & 6.40 & 7.20 & 6.60 \\
\hline 9 & Optimis & 7.00 & 6.40 & 8.20 & 7.40 \\
\hline
\end{tabular}


Stereotip atau skema gender tampaknya lebih "diaktifkan" di kalangan pria daripada wanita.

Kemudian, setelah dimasukkan variable mengenai identity salience, mengenai sejauh mana seseorang menganggap penting politik. Tampak ada perbedaan yang menarik antara responden yang melaporkan tingkat ketertarikan politik yang tinggi dan mereka yang kurang tertarik pada politik. Responden yang memiliki ketertarikan politiktinggimembedakankualitasantarakandidat laki-laki dan perempuan. Nilai signifikan muncul dalam popularitas kandidat. Skor popularitas rata-rata saat calon wanita adalah 3,72 , namun saat calon pria skor adalah 4,51. Dipahami bahwa responden yang tingkat pengetahuan mengenai politik yang tinggi stereotip, ini konsisten
Di Indonesia, kerap disangka jika seseorang menganggap bahwa politisi perempuan lebih baik dari politisi laki-laki, maka dikecam sebagai radikal dan ekstrim. Namun, peneliti juga perlu memperhatikan jika analisis eksperimen merupakan perbandingan langsung. Analisis ditarik dari penilaian responden pada kinerja tunggal.

Perempuan perlu mengubah anggapan sebagai warga kelas dua. Tahun 2001, Indonesia memiliki presiden perempuan pertama. Berkaca pada masa itu, karier politik Megawati Soekarnoputri sebagai presiden dirasa penuh kontroversi. Tidak hanya kemampuan memimpin yang menjadi sorotan media dan warga, namun kehidupan pribadi juga menjadi perhatian. Seiring berjalannya waktu, politisi

Tabel 3. Analisis Regresi Pidato

\begin{tabular}{lll|l|l|}
\hline & Model 1 & Model 2 & \\
\hline & $\mathrm{B}$ & Beta & $\mathrm{B}$ & Beta \\
\hline Constant & 15.8 & & 16.45 & \\
\hline Stimulasi Gender & 1.84 & .12 & & \\
\hline Jenis Kelamin Responden & -1.09 & -.08 & & \\
\hline Identifikasi JK Laki-laki & & & 3.44 & 0.18 \\
\hline Identifikasi JK Perempuan & & & 0.7 & 0.3 \\
\hline Identity Salience & -0.22 & -.05 & -.9 & -.04 \\
\hline
\end{tabular}

Tabel 4. Korelasi Antara Gender Kandidat dengan Identity Salience Responden

\begin{tabular}{lll} 
Popularity & Kandidat Perempuan & Kandidat Laki-Laki \\
\hline $\begin{array}{l}\text { Identity Salience Tinggi } \\
\text { Nilai Kandidat }\end{array}$ & 3.72 & 4.51 \\
$\begin{array}{l}\text { Identity Salience Rendah } \\
\text { Nilai Kandidat }\end{array}$ & 4.7 & 4.66
\end{tabular}

dengan penelitian terdahulu dari Koch (2002).

Dari tabel yang yang disudah disajikan, ditarik kesimpulan adanya gender blindness pada perempuan dan gender favoritism (pilih kasih) di pada responden pria. Peneliti mengurai masalah ini dengan memberi pengertian bahwa bagi perempuan, gender blindness bisa dikarenakan banyak perempuan merasa kurang berprestasi. Meski sudah banyak perempuan yang membuat gebrakan, namun image perempuan masih dianggap yang belum sebagus politisi laki-laki. perempuan lainnya banyak yang dianggap sukses menarik perhatian khalayak lewat debat TV dan kampanye. Bagaimana Menteri Susi yang menjadi media darling. Namun ada juga politisi perempuan yang dianggap tidak pantas karena disebut melakukan korupsi. Angelina Sondakh melakukan korupsi proyek wisma atlet SEA Games di Palembang. Prestasi yang sebelumnya dimiliki oleh Angelina menjadi tidak tampak karena isu negative tersebut. 


\section{Gender stereotiping}

Lembaga legislatif memiliki arti yang strategis dalam pengambilan keputusan di sektor publik. Tidak mengherankan jika jabatan di lembaga ini diperebutkan oleh berbagai pihak yang terwakili dalam partai politik. Setelah ada ketentuan mengenai kuota $30 \%$ dalam pencalonan anggotalegislatif,partai-partaipolitikyangberada di wilayah penelitian sudah melaksanakan hal tesebut. Namun data paska pemilu menunjukkan hasil yang berbeda di Kabupaten Minahasa dan di Kabupaten Wonosobo. Di Kabupaten Minahasa, jumlah anggota legislatif perempuan yang terpilih pada pemilu 2014 di atas $42,86 \%$ sementara di Kabupaten Wonosobo hanya 4,4\%.

Aspek sosial di kedua Kabupaten tersebut tampaknya mempengaruhi keterpilihan calon anggota legislatif perempuan. Berbagai aspek seperti sosial budaya dan kesejarahan tampaknya iktu mempengaruhi hal ini. Di Kabupaten Minahasa, sejak 1908, sudah ada 6.056 murid perempuan Minahasa/Manado di antara 12.276 murid perempuan yang terdapat di luar Pulau Jawa dan Madura, sementara itu di Jawa baru terdapat 280 murid perempuan. Dalam kebanyakan sekolah/perguruan tinggi terdata lebih banyak perempuan daripada laki-laki, padahal berdasarkan data kependudukan kabupaten/kota se-Sulut yang dirinci menurut jenis kelamin pada 2003 menunjukkan penduduk laki-laki lebih banyak daripada penduduk perempuan. (http://manado.tribunnews.com). Data ini menunjukkan bahwa sejak dulu anak perempuan Minahasa diberi kesempatan yang sama dengan anak laki-laki Minahasa untuk bersekolah. Tidaklah heran bila sejarah mencatat bahwa beberapa perempuan Minahasa menjadi pelopor dan pemimpin di bidangnya masing-masing.

Sementara itu, kondisi yang berbeda ditemukandiKabupaten Wonosobo. Secarasosial, ada beberapa hal yang menonjol di sini. Pertama, dari sisi pendidikan, di Kabupaten ini masih berada pada tingkat yang rendah. Jika di tingkat Sekolah Dasar, Angka Partisipasi Kasar (APK) sudah mencapai $100 \%$, maka pada tahun 2013, APK tingkat SLTP adalah $73,13 \%$ dan tingkat
SLTA hanya 38,40\% (https://wonosobokab.bps. go.id/linkTableDinamis/view/id/136). Angka ini cukup rendah dan tampaknya berkontribusi pada rendahnya partisipasi dalam bidang politik.

Bagi banyak perempuan di daerah ini, bidang politik tidak cukup menarik perhatian dan justru banyak di antara mereka yang lebih memilih menjadi tenaga kerja wanita (TKW) di luar negeri. Kabupaten Wonosobo adalah kantong pengirim TKW terbesar ketiga di Jawa Tengah. Sayangnya, bekerja menjadi TKW tidak menjadi solusi jangka panjang bagi mereka dan keluarganya karena penghasilan bekerja di luar negeri lebih banyak dihabiskan untuk keperluan konsumtif sepertirumah megah, mobil,perhiasan, fashion dan pesta (Susilo, Susilastuti,2014).

Berdasarkan penelusuran mendalam dalam penelitian, dapat diketahui bahwa bidang politik tidak populer di kalangan perempuan. Politik terlalu kuat diidentikkan dengan lakilaki. Banyak perempuan yang aktif di organisasi kemasyarakatan seperti Aisyiah dan Muslimat NU, akan tetapi mereka lebih memilih tetap berkiprah di wilayah itu dan tidak menggunakan aktifitas atau popularitasnya untuk menjadi anggota legislatif. Hal ini diperkuat lagi oleh doktrin keagamaan bahwa laki-lakilah yang menjadi pemimpin dan bukan perempuan. Hal ini dibuktikan oleh rendahnya kepemimpinan perempuan pada posisi yang strategis. Di lembaga ekesekutif pemimpin perempuan juga belum banyak yang duduk di jajaran strategis. Selama perjalanan sejarah kabupaten Wonosobo, posisi tertinggi yang dijabat perempuan adalah wakil bupati, itu pun hanya satu periode yakni 2010-2015. Camat perempuan juga hanya 2 dari 15 kecamatan. Kades perempuan hanya kisaran 10-15 orang dari 236 desa di kabupaten Wonosobo, kepala dinas/instansi pemerintah daerah masih didominasi oleh kaum laki-laki.

Hasil penelitian eksperimen penelitian ini menunjukkan bahwa stereotip gender di kalangan responden masih cukup kuat. Stereotip adalah pandangan dan penilaian terhadap kelompok tertentu secara umum. Stereotip gender adalah kategori luas yang merefleksikan 
kesan dan keyakinan tentang apa perilaku yang tepat untuk laki-laki dan perempuan. Pada perempuan, misalnya dilekatkan sifat-sifat telaten, rajin atau suka berpikir emosional. Sementara itu pria dianggap memiliki sifat-sifat sebaliknya, seperti keras, tegas dan rasional. Banyak steoreotip yang bersifat bias karena sifatnya yang menggenalisir. Akan tetapi, dengan segala kelemahannya, steoreotip masih sering digunakan sebagai salah satu cara berpikir. Pada masa kampanye menjelang pemilu, para calon legislatif perempuan banyak menggunakan pendekatan yang menguatkan stereotip gender. Salah satu calon anggota legislatif, misalnya, menempatkan diri sebagai "ibu". Ibu identik dengan sifat-sifat lembut dan nurturing. Hal ini dijadikan sebagai salah satu daya tarik untuk memikat hati calon pemilih. Untuk lebih meyakinkan calon pemilih dengan sifat-sifatkeibuannyadigunakan slogan "Pokokke Melu Ibu" yang artinya "Pokoknya Ikut Ibu". Forum-forum yang digunakan untuk menemui calon pemilih juga merupakan forum di mana para pemilih perempuan banyak beraktifitas seperti di kelompok arisan, kelompok tani, kempompok kesenian dan pengajian. Calon anggota legislatif mempercayai bahwa pendekatan ini bisa menarik simpati calon pemilih. Di luar forum ini, mereka juga mengadakan kunjungan pribadi dan dibakukan dalam sebuah istilah yang mudah diingat, SLJ (Sonjo, Layat, Jagong), yang artinya silaturahmi, melayat dan menghadiri undangan warga.

Pendekatan sosial juga dipilih oleh politisi perempuan di Kabupaten Minahasa. Di sana, upacara kematian menjadi slah satu sarana menjalin kedekatan dengan pemilih. Di Minahasa, setelah 40 hari seseorang meninggal, masih diadakan upacara tradisi keagamaan setiap minggu. Pada kesempatan itu, tetangga saudara dan kawan-kawan keluarga almarhum akan datang untukk berdoa dan menunjukkan simpati. Politisi tidak mengadakan pidato atau retorika, tetapi hanya datang saja. Hal ini sesuai dengan anggapan dalam Ilmu Komunikasi bahwa "kita tidak dapat tidak berkomunikasi".
Diam pun merupakan komunikasi Pada kesempatan yang lain, para anggota legislatif juga menggunakan pendekatan retorika seperti dipaparkan pada bagian awal tulisan ini. Retorika klasik menggunakan paduan dari tiga komponen: ethos, pathos dan logos. Ethos adalah sumber kepercayaan. Calon Anggota legislatif harus dapat di percaya oleh audience-nya. Terdapat dua kategori calon anggota legislatif yaitu mereka yang benar-benar memiliki kompetensi menjadi anggota legislatif dan dan mereka yang dicalonkan untuk memenuhi kuota perempuan $30 \%$. Untuk kategori pertama, mereka relatif memiliki ethos yang baik karena memiliki sesuatu yang ditawarkan kepada calon pemilih. Pada umumnya mereka juga sudah memiliki pengalaman di organisasi. Sementara, untuk kategori yang kedua memiliki sifat sebaliknya. Ethos mereka belum muncul karena pencalonan mereka sebagai calon anggota legislatif adalah pengalaman pertama sebagai calon politisi.

Calon anggota legislatif perempuan yang memiliki ethos yang baik, cenderung akan diikuti oleh pathos yang baik pula. Pathos yang artinya himbauan emosional, atau sesuatu yang berhubungan dengan emosi manusia, karena saat menyampaikan orasi atau topik permasalahan, seringkali hal tersebut bersangkutan dengan perasaan pendengar dan terkadang menimbulkan banyak empati atau bahkan simpati dari pendengar atau audience. Mereka mampu membawa suasana pendengarnya ke dalam topik masalah yang disampaikannya. Jika respon yang di harapkan muncul, maka pembicara berhasil memiliki aspek Pathos di dalam dirinya. Hal ini ditunjang pula oleh ketatabahasaan dan gaya bicara yang dimilikinya.

Pada aspek ketiga,logos, tampak bahwa para calon legislatif perempuan memiliki strategi komunikasi yang berbeda. Ada perbedaan yang mendasar saat mereka menyampaikan argumentasi pada gender yang berbeda. Pada audiens laki-laki, mereka menyampaikan argumentasi yang rasional, riil atau nyata dan dapat dibuktikan tidak hanya sekadar janji tapi harus ada bukti. Sedangkan terhadap khalayak 
perempuan karena ada kedekatan emosional, maka yang dikedepankan adalah dengan rasa dan jiwa keibuan yang saya miliki melalui pendekatan sosiologis dan rasa simpati dan empati.

Hal ini secara nyata menunjukkan bahwa para politisi perempuan juga ikut melanggengkan stereotip gender. Konsep feminine yang dimiliki perempuan harus beriringan dengan kasih sayang. Jika seorang perempuan memilih untuk menjadi politisi dan menduduki jabatan tertentu, maka kemampuan yang dimiliki bertujuan untuk mensejahterakan. Nilai yang dimiliki perempuan tidak hanya bersifat nurturing, namun mencakup logika dan tujuan yang jelas.

\section{Simpulan}

Indonesia yang luas, masih menganut budaya patriarki di berbagai daerah. Payung hukum yang mendorong partisipasi politik perempuan perlu didukung dengan perubahan sosial yang memadai. Ada sebuah ambiguitas di mana perempuan diizinkan untuk beraktifitas di sektor publik dan berkontribusi dalam pendapatan keluarga, akan tetapi ketika mereka akan menempati posisi pemimpin, masih banyak pembatasan. Pembatasan itu berasal dari argumen agama maupun sosial budaya.

Stereotip gender masih melekat dengan kuat di benak masyarakat. Perempuan diberi label dan penilaian yang berbeda dengan lakilaki. Pada saat yang sama, para politisi dan calon politisi perempuan pun berkomunikasi dengan melanggengkan stereotip ini. Citra perempuan sebagai ibu yang mengayomi dan mengasihi digunakan oleh calon politisi untuk meraih suara dalam pemilu

Strategi komunikasi yang diterapkan oleh politisi perempuan masih dalam rangka mengukuhkan stereotip yang ada. Mereka melakukan komunikasi dengan cara yang lebih nurturing, memposisikan diri sebagai "ibu" dan berkomunikasi dengan kelembutan, baik verbal maupun nonverbal. Mereka memilih sasaran pemilih perempuan sebagai sasaran utama dan laki-laki sebagai sasaran berikutnya. Cara ini dianggap cukup beralasan karena jumlah pemilih perempuan lebih banyak dari pemilih laki-laki. Sementara itu, untuk partai politik diharapkan memberi ruang dan kesempatan yang besar untuk perempuan dalam rekrutmen politik. Saat ini, ada kecenderungan partai politik hanya menempatkan perempuan sebagai calon anggota legislatif untuk memenuhi kuota saja. Posisi sebagai politisi tidak bisa dibentuk secara instan. Beberapa politisi dalam penelitian ini sudah memiliki pengalaman panjang di masyarakat sejak mereka masih muda dengan aktif di organisasi yang langsung berhadapan dengan persoalan di masyarakat.

\section{Daftar Pustaka}

Mulyana, Deddy. (2007). Metode Penelitian Komunikasi. Bandung: Rosdakarya.

Popkin, Samuel L. (1991). The Reasoning Voter: Communication and Persuasion in Presidential Campaigns. Chicago: University of Chicago Press. Sreberny, Annabelle \& Liesbet van Zoonen. (2000). Gender, Politics and Communication Cresskill:HamptonPress. Uchjana, Onong. (2007). Ilmu, Teori, dan Fisafat Komunikasi. Bandung: Citra Aditya Bakti Parawansa, Indar Khofifah (2002) Hambatan terhadap Partipasi Politik Perempuan di Indonesia. Jakarta: International IDEA

\section{Jurnal}

Jenssen, Anders Todal \& Toril Aalberg (2006) „Party-leader Effects in Norway. A Multimethods Approach", Electoral Studies 25

Marcus, George E. (1991) „Emotions and Politics: Hot Cognitions and the Rediscovery of Passion", Social Science Information 32:195-232. Marcus, George E. (1988) „The Structure of Emotional Response: 1984 Presidential Candidates", The American Political Science Review, Vol. 82: 737-761.

\section{Internet}

Ramadhan, Hasan. 19 Mei 2014. Menurunnya Jumlah Keterwakilan Perempuan di 
Parlemen. Tersedia dalam: http://www. jurnalperempuan.org/menurunnya-jumlahketerwakilanperempuan-di-parlemen.html

Puskapol FISIP UI. 9 Oktober 2014. Ini Dia Profil Anggota Legislatif 2014-2019.

Tersedia dalam :

http://www.republika.co.id/berita/koran/ teraju/14/10/09/nd6caa-ini-diaprofil-anggotalegislatif-20142019

http://www.dpr.go.id/dokakd/dokumen/ makalah_STRATEGI MENINGKATKAN KETERWAKILAN_PEREMPUAN OlehIgnatius Mulyono.pdf ht tps://wonosobokab.bps.go.id/ linkTableDinamis/view/id/136

Suara Merdeka, harian, 21 Maret 2016. Keterwakilan Perempuan Rendah di Legislatif. Tersedia dalam: http://berita.suaramerdeka.com/ smcetak/keterwakilan-perempuan-rendahdilegislatif/

ht tps://wo nos obokab.bps.go.id/ linkTableDinamis/view/id/136 